\title{
Effect of dietary supplementation with insect fats on growth performance, digestive efficiency and health of rabbits
}

\author{
Laura Gasco', Sihem Dabbou², Angela Trocino ${ }^{3}$, Gerolamo Xiccato ${ }^{4}$, Maria Teresa Capucchio ${ }^{2}$, Ilaria Biasato ${ }^{1}$, \\ Daniela Dezzutto ${ }^{5}$, Marco Birolo ${ }^{4}$, Marco Meneguz ${ }^{1}$, Achille Schiavone ${ }^{2,6,7^{*}}$ (D) and Francesco Gai ${ }^{6}$
}

\begin{abstract}
Background: The present work aimed at evaluating the effect of the dietary replacement of soybean oil (S) by two types of insect fats extracted from black soldier fly larvae ( $\mathrm{H}$, Hermetia illucens $\mathrm{L}$.) and yellow mealworm larvae $(\mathrm{T}$, Tenebrio molitor $\mathrm{L}$.) on growth performance, nutrient digestibility, blood parameters, intestinal morphology and health of growing rabbits.

Methods: At weaning, 200 crossbred rabbits (36 days old) were allotted to five dietary treatments (40 rabbits/group): a control diet (C) containing $1.5 \%$ of soybean oil and four experimental diets where soybean oil was partially (50\%) or totally (100\%) substituted by H (H50 and H100) or T (T50 and T100) fats. Total tract digestibility was evaluated on 12 rabbits per treatment. The growth trial lasted $41 \mathrm{~d}$ and, at slaughtering (78 days old), blood samples were collected from 15 rabbits per treatment, morphometric analyses were performed on duodenum, jejunum and ileum mucosa, and samples of liver, spleen and kidney were submitted to histological evaluation.

Results: No difference was observed between the control and the experimental groups fed insect fats in terms of performance, morbidity, mortality and blood variables. The addition of $\mathrm{H}$ and $\mathrm{T}$ fats did not influence apparent digestibility coefficients of dry matter, protein, ether extract, fibre fractions and gross energy. Gut morphometric indices and organ histopathology were not affected by dietary inclusion of $\mathrm{H}$ and $\mathrm{T}$ fats.

Conclusions: $\mathrm{H}$ and $\mathrm{T}$ fats are suitable sources of lipid in rabbit diets to replace soybean oil without any detrimental effect on growth performance, apparent digestibility, gut mucosa traits and health.
\end{abstract}

Keywords: Blood, Digestibility, Growing rabbit, Gut health, Insect fats, Performances

\section{Background}

Several researches focused on the influence of the dietary supplementation of different fat sources such as animal oil or plant oilseeds [1-3] on performances, digestibility, health status, meat and fatty acid (FA) composition of rabbit meat.

The $60 \%-70 \%$ increase of animal products consumption expected by 2050 has pushed research to investigate new raw materials for animal feeds [4]. In this context, insects are very interesting as innovative feed for fish and

\footnotetext{
* Correspondence: achille.schiavone@unito.it

${ }^{2}$ Department of Veterinary Science, University of Turin, Largo Paolo Braccini

2, 10095 Grugliasco, Turin, Italy

${ }^{6}$ Institute of Science of Food Production, National Research Council, Largo

Paolo Braccini 2, 10095 Grugliasco, Turin, Italy

Full list of author information is available at the end of the article
}

terrestrial animals due to their valuable chemical composition and their claimed sustainability [5, 6]. So far, research has been mainly addressed to the protein content of insect larvae meals in fish, poultry and pigs feeds to replace conventional protein sources (mainly fishmeal and soybean meals) [7-9]. The insect species most investigated were black soldier fly (H, Hermetia illucens L.) and yellow mealworm (T, Tenebrio molitor L.) $[9,10]$.

Nevertheless, insects have different lipid content (ether extract from $5 \%$ to $40 \%$ of dry matter, DM) and FA profile related to the species and the rearing substrate $[6$, $11,12]$. When processing larvae and in order to increase the protein content and the storability of the insect processed meals, some authors underlined the importance of defatting larvae meal [13, 14]. Unlike protein

(c) The Author(s). 2019 Open Access This article is distributed under the terms of the Creative Commons Attribution 4.0 International License (http://creativecommons.org/licenses/by/4.0/), which permits unrestricted use, distribution, and reproduction in any medium, provided you give appropriate credit to the original author(s) and the source, provide a link to the Creative Commons license, and indicate if changes were made. The Creative Commons Public Domain Dedication waiver (http://creativecommons.org/publicdomain/zero/1.0/) applies to the data made available in this article, unless otherwise stated. 
meals, which use in farm animal feeding is restricted (except for fish) in Europe (Reg. EC 999/2001), there are no prohibitions on the use of insect fats as a raw material for animal compound feeds [15-17].

Concerning the insect species mentioned above, Hermetia illucens is a worldwide distributed Diptera which is reared for its ability to convert low value substrates into valuable products $[12,18]$, and whose fat is characterised by high levels of saturated fatty acids (SFA), mainly lauric (C12:0) acid [19]. Tenebrio molitor is a Coleoptera which larvae, considered as pests of stored grains, contain from $15 \%$ to $45 \% \mathrm{DM}$ of fat, mostly palmitic (C14:0), oleic (C18:1 n-9) and linoleic (C18:2 n-6) acids $[6,19]$.

So far, the use of insect lipids in animal feeding has received little attention. Researchers investigated the effects of the dietary inclusion of $\mathrm{H}$ fat in partial or total replacement of soybean oil (S) without negative effects on performance and carcass traits of broiler chickens $[17,20]$. Li et al. [15] evaluated the effect of $\mathrm{H}$ fat in substitution of up $100 \% \mathrm{~S}$ in diets for juvenile carps and did not find negative effects on growth, feed efficiency or chemical composition of fish fillets. Recently, Kierończyk et al. [16] completely substituted soybean oil with Tenebrio molitor or Zophobas morio fat (5\% of dietary inclusion) in broiler diets without adverse consequences on growth performance and nutrient digestibility.

As far as rabbits are concerned, to the best of our knowledge only two old researches have been carried out using insect meal (silkworm) replacing soybean meal $[21,22]$ and only two research has been performed using insect fat $[23,24]$ in diets for growing rabbits. The aim of this research was therefore to evaluate the effect of $\mathrm{H}$ and $T$ fats used as partial or total substitute of soybean oil on growth performances, digestibility, blood metabolites, intestinal morphology and histological traits of growing rabbits.

\section{Methods}

The Ethical Committee of the University of Turin (Italy) approved the experimental protocol (Ref. $386638,4 / 12 / 2017)$. The trial was carried out at the experimental rabbit facility of the Department of Agricultural, Forest, and Food Sciences (DISAFA; University of Turin, Turin, Italy).

\section{Diets}

An experimental control diet (C) containing $1.5 \%$ soybean oil and formulated to satisfy growing rabbits requirements [25] was tested against four experimental diets where S was partially $(50 \%)$ or totally $(100 \%)$ substituted by $\mathrm{H}$ (H50 and $\mathrm{H} 100)$ or $\mathrm{T}$ (T50 and T100) fats (Table 1). All diets were pelleted at the feed mill of the experimental facility at the beginning of the trial and stored in darkness and fresh to protect against lipid oxidation and degradative processes.

\section{Animals and experimental conditions}

After weaning at 36 days of age, 200 commercial crossbred rabbits (Hycole, France) purchased from a commercial farm (Verzuolo, Cuneo, Italy), $1051 \pm 138 \mathrm{~g}$ live weight (LW), were randomly allocated in individual wire-net cages $(41 \mathrm{~cm} \times 30 \mathrm{~cm} \times 28 \mathrm{~cm}$ height $)$. Forty rabbits, homogeneous by LW and variability, were assigned to each dietary treatment. The rabbitry had automatic control of environmental temperature $\left(22 \pm 2{ }^{\circ} \mathrm{C}\right)$ and photoperiod (16L:8D). The rabbits were fed ad libitum and had free access to clean drinking water during the whole trial that lasted $41 \mathrm{~d}$, until 77 days of age.

At 78 days of age, rabbits were slaughtered in an experimental slaughterhouse. Data of dressing percentage, carcass traits and meat quality, and chemical composition were determined but not reported in this paper.

\section{Growth performance and health status}

During the trial, mortality and morbidity were controlled daily by the same observer according to Gidenne et al. [26]. LW and feed intake were recorded per every rabbit on a weekly basis. At the end of the trial, the averages of LW, daily feed intake (ADFI), daily weight gain (ADG) and feed conversion ratio (FCR) were calculated.

\section{Digestibility trial}

The apparent digestibility coefficient (ADC) and the nutritive value of experimental diets were measured during an in vivo digestibility assay performed according to the European standardised method [27]. The trial involved 60 rabbits (12 rabbits per dietary treatment) among those monitored for the fattening trial and started at 50 days of age. Faeces were daily collected per each rabbit and four consecutive days $(09: 00 \mathrm{~h})$ and stored at $-20{ }^{\circ} \mathrm{C}$ until analyses.

\section{Chemical analyses and diet fatty acid profile}

Diets and faeces were analysed to determine the contents of DM (method 934.01), ash (method 967.05), crude protein (CP - method 2001.11), and starch (amyloglucosidase $\alpha$ amylase method, 996.11) using AOAC methods [28] following harmonised procedures [29]. Ether extract (EE) was analysed after acid hydrolysis [30]. The sequential procedure and the filter bag system (Ankom Technology, Macedon, NY, USA) were used in the analyses of fibre fractions: neutral detergent fibre (aNDF) was analysed according to Mertens [31], assayed with a heat stable alfa-amylase and expressed inclusive of residual ash, without sodium sulphite; acid detergent fibre (ADF), expressed inclusive of residual ash, was analysed according to AOAC [28] (method 973.187); lignin 
Table 1 Ingredients ( $\mathrm{g} / \mathrm{kg}$ as fed) and chemical composition (\% DM) of experimental diets

\begin{tabular}{|c|c|c|c|c|c|}
\hline \multirow[t]{2}{*}{ Ingredients } & \multicolumn{5}{|c|}{ Experimental diets } \\
\hline & $\bar{C}$ & $\mathrm{H} 50$ & $\mathrm{H} 100$ & $\mathrm{~T} 50$ & $\mathrm{~T} 100$ \\
\hline Dehydrated alfalfa meal (17 g CP/100 g) & 320 & 320 & 320 & 320 & 320 \\
\hline Alfalfa hay & 75 & 75 & 75 & 75 & 75 \\
\hline Wheat bran & 235 & 235 & 235 & 235 & 235 \\
\hline Barley meal & 100 & 100 & 100 & 100 & 100 \\
\hline Dried sugar beet pulp & 160 & 160 & 160 & 160 & 160 \\
\hline Soybean meal (44 g CP/100 g) & 70 & 70 & 70 & 70 & 70 \\
\hline Soybean oil & 15 & 7.5 & - & 7.5 & - \\
\hline Hermetia illucens fat ${ }^{a}$ & - & 7.5 & 15 & - & - \\
\hline Tenebrio molitor fat ${ }^{\mathrm{b}}$ & - & - & - & 7.5 & 15 \\
\hline Cane molasses & 12 & 12 & 12 & 12 & 12 \\
\hline Dicalcium phosphate & 3 & 3 & 3 & 3 & 3 \\
\hline Sodium chloride & 4 & 4 & 4 & 4 & 4 \\
\hline L-methionine (98 g methionine/100 g) & 1 & 1 & 1 & 1 & 1 \\
\hline Vitamin-mineral premix ${ }^{c}$ & 5 & 5 & 5 & 5 & 5 \\
\hline \multicolumn{6}{|l|}{ Chemical composition } \\
\hline Dry matter, \% & 89.4 & 90.0 & 89.2 & 89.5 & 89.6 \\
\hline Ash, \% DM & 8.58 & 7.67 & 7.77 & 8.18 & 7.75 \\
\hline Crude protein, \% DM & 17.0 & 16.4 & 16.8 & 16.8 & 16.3 \\
\hline Ether extract, \% DM & 4.22 & 4.07 & 3.92 & 4.13 & 3.87 \\
\hline Neutral detergent fibre (aNDF), \% DM & 40.2 & 42.5 & 41.7 & 39.8 & 40.5 \\
\hline Acid detergent fibre (ADF), \% DM & 21.7 & 23.8 & 23.0 & 21.4 & 22.8 \\
\hline Acid detergent lignin (ADL), \% DM & 4.81 & 5.09 & 5.09 & 4.87 & 5.02 \\
\hline Gross Energy, MJ/kg DM & 18.50 & 18.63 & 18.50 & 18.75 & 18.62 \\
\hline
\end{tabular}

$C$, control diet; $H 50$ and $H 100$, diets with Hermetia illucens fat; $T 50$ and $T 100$, diets with Tenebrio molitor fat; $D M$, dry matter; $C P$, crude protein

${ }^{a}$ Hermetia illucens fat was provided by Hermetia Deutschland GmbH \& Co. KG (Baruth / Mark, Germany)

${ }^{\mathrm{b}}$ Tenebrio molitor fat was provided by Ynsect (Evry, France)

'Premix provided per kg of complete diet: vitamin A 16,000 IU; vitamin $D_{3} 1,600 \mathrm{IU}$; vitamin E acetate $30 \mathrm{mg}$; vitamin $B_{1} 0.8 \mathrm{mg}$; vitamin $B_{6} 1.65 \mathrm{mg}$; niacin $40 \mathrm{mg}$; folic acid $1 \mathrm{mg}$; Mn 30 mg; Fe $116 \mathrm{mg}$; Cu $12.5 \mathrm{mg}$; Zn $60 \mathrm{mg}$; Co $0.45 \mathrm{~g}$; Ca $1.3 \mathrm{mg}$; Se $0.3 \mathrm{mg}$

was analysed with sulphuric acid according to Van Soest et al. [32]. Gross energy (GE) contents of diets and faeces were measured by adiabatic bomb calorimeter (IKA C200, Staufen, Germany).

The FA composition of insect lipids and feeds was determined according to Trocino et al. [33]. The fat was extracted by accelerated solvent extraction (Application Note 334; ASE ${ }^{\bullet}$, Dionex, Sunnyvale, CA, USA) using two extraction cycles. The extracted lipids were initially trans-methylated as fatty acid methyl esters (FAMEs). An internal standard (13: 1 methyl ester) was added to the extracts before methylation. After centrifugation, the surnatant was submitted to two-dimensional gas chromatography $(\mathrm{GC} \times \mathrm{GC})$ by using an Agilent $7890 \mathrm{~A}$ Gas Chromatograph (Agilent Technologies, Santa Clara, CA, USA). Supelco SP 2560 (Sigma-Aldrich, St. Louis, MO, USA) was used as the first capillary column $(75 \mathrm{~m} \times 0.18$ $\mathrm{mm}$ internal diameter, $0.14 \mu \mathrm{m}$ film thickness), with hydrogen as carrier. J\&W HP 5 ms (Agilent Technologies) was used as the second capillary column $(3.8 \mathrm{~m} \times 0.5$ $\mathrm{mm}$ internal diameter, $0.25 \mu \mathrm{m}$ film thickness), with hydrogen as carrier. The FA were identified by comparing the retention time of standard FAMEs mixture (Supelco 37 - component FAME Mix, 47,885 - U). Individual FAMEs were expressed as the percentage of the total area of eluted FAMEs.

\section{Serum biochemistry parameters}

At slaughtering, blood samples were collected from 15 rabbits per treatment at the moment of jugular exsanguination and put into $2.5 \mathrm{~mL}$ serum-separating tubes. The tubes without anticoagulant were left to clot in a standing position at room temperature for approximately two hours to obtain serum. The serum was separated by means of centrifugation at $700 \times g$ for 15 min and frozen at $-80^{\circ} \mathrm{C}$ until analysis. The total proteins (TP) were quantified by the "biuret method" (Bio Group Medical System kit; Bio Group Medical System, 
Talamello, Italy). Alanino-aminotransferase (ALT), aspartate-aminotransferase (AST), alkaline phosphatase (ALP), gamma glutamyl transferase (GGT), triglycerides, cholesterol, calcium, phosphorus, iron, uric acid, urea, lactate dehydrogenase (LDH) and creatinine serum concentrations were analysed with enzymatic methods using the Screen Master Touch automated instrument (Hospitex 130 Diagnostics S.r.l., Sesto Fiorentino, Italy).

\section{Histomorphological variables}

The same 15 rabbits per treatment used for serum biochemistry determinations were used for anatomo-pathological investigations. Segments (approximately $5 \mathrm{~cm}$ in length) of duodenum (after the pylorus), jejunum (middle portion) and ileum (before ileo-caecal junction) were excised and flushed with $0.9 \%$ saline to remove all the intestinal content. Samples of liver, spleen and kidney were also collected. The collected samples were fixed in $10 \%$ buffered formalin solution and submitted to morphometric analysis (intestine tracts) and histopathological examination (other organs). The tissues were routinely embedded in paraffin wax blocks, sectioned at $5 \mu \mathrm{m}$ thickness and mounted on glass slides. Intestinal sections were submitted to haematoxylin-eosin (HE) staining, with a total of five serial sections prepared for each intestinal segment. The same slide among the serial sections was examined by light microscopy and captured with a Nikon DS-Fi1 digital camera coupled to a Zeiss Axiophot microscope using a $2.5 \times$ objective lens. NIS-Elements F software was used for image capturing. Morphometric analysis was performed by Image ${ }^{\oplus}$-Pro Plus software. The evaluated morphometric indices were: villus height ( $\mathrm{Vh}$, from the villous tip to the crypt bottom), crypt depth ( $\mathrm{Cd}$, from the crypt bottom to the submucosa) and the villus height to crypt depth ratio (Vh/Cd; Additional file 1) [34, 35]. Morphometric measurements were performed on 10 well-oriented and intact villi and 10 crypts chosen from each gut segment.

Organ sections were submitted to HE staining and examined by light microscopy. The observed histopathological findings were evaluated using a semi-quantitative scoring system as follows: absent (score $=0$ ), mild (score $=1)$, moderate $($ score $=2$ ) and severe $($ score $=3)$. The following histopathological alterations were evaluated: inflammatory infiltrates and degenerative changes in liver and kidney and white pulp hyperplasia and depletion in spleen. All slides were assessed blinded by three observers and the discordant cases were reviewed at a multi-head microscope until a consensus was reached.

\section{Statistical analyses}

The statistical analyses were performed using the IBM SPSS software package (IBM Corp. Released 2012. IBM SPSS Statistics for Windows, Version 21.0. IBM Corp,
Armonk, NY). Shapiro-Wilk's test established normality or non-normality of distribution. One-way ANOVA was used to evaluate the effect of experimental diets on growth performance, apparent digestibility coefficients, serum biochemical parameters and intestinal morphometric indices. The assumption of equal variances was assessed by Levene's homogeneity of variance test. Mortality rate was analysed by Chi-square test, using the $\mathrm{C}$ group as the reference. Differences amongst groups were evaluated by the Duncan's test. Histopathological scores were analysed by Kruskal-Wallis test (post-hoc test: Dunn's Multiple Comparison test).

For all statistical analyses significance was declared at $P \leq 0.05$ and a statistical trend was considered for $0.05<P \leq 0.10$. The results are presented as the means and standard error of the means (SEM).

\section{Results}

\section{Diet composition and fatty acid profile}

Diets were comparable in terms of main crude protein (on average $16.6 \% \mathrm{DM}$ ) and gross energy contents (18.6 $\mathrm{MJ} / \mathrm{kg} \mathrm{DM})$, despite some differences in aNDF and ADF contents (Table 1).

The substitution of $\mathrm{S}$ with insect fats modified the FA profile of the lipids in the diets (Table 2). In fact, lauric acid (C12:0) and, thus, total SFA rate were the highest in $\mathrm{H}$ fat and $\mathrm{H}$ diets; oleic acid (C18:1 n-9) and MUFA rates were the highest in $\mathrm{T}$ fat and $\mathrm{T}$ diets; whereas, linoleic acid (C18:2 n-6) and PUFA dominated the FA profile of $\mathrm{S}$ and $\mathrm{C}$ diets.

Table 2 Fatty acids profile (\% of total FA) of dietary fats and experimental diets

\begin{tabular}{|c|c|c|c|c|c|c|c|c|}
\hline \multirow{2}{*}{$\begin{array}{l}\text { Fatty } \\
\text { acids }\end{array}$} & \multicolumn{3}{|c|}{ Dietary fats } & \multicolumn{5}{|c|}{ Experimental diets } \\
\hline & $S$ & $\mathrm{H}$ & $\mathrm{T}$ & $\mathrm{C}$ & $\mathrm{H} 50$ & $\mathrm{H} 100$ & T50 & $\mathrm{T} 100$ \\
\hline 2:0 & 0.02 & 48.0 & 0.23 & 0.05 & 9.12 & 03 & 0.75 & 0.30 \\
\hline 14:0 & 0.08 & 10.3 & 2.22 & 0.09 & 2.11 & 4.47 & 0.97 & 1.33 \\
\hline 6:0 & 10.4 & 12.7 & 1 & 12.1 & 15.7 & 16 & 17.3 & 18.4 \\
\hline 18:0 & 4.43 & 1.90 & 2.31 & 2.84 & 2.62 & 2.08 & 2.65 & 2.22 \\
\hline 16:1 n-7 & 0.09 & 3.20 & 1.66 & 0.12 & 1.31 & 1.99 & 0.70 & 1.04 \\
\hline 18:1 n-9 & 23.0 & 9.11 & 37.8 & 20.1 & 17.3 & 12.7 & 24.6 & 27.3 \\
\hline $18: 2 n-6$ & 51.5 & 9.00 & 33.2 & 52.1 & 40.9 & 31.0 & 42. 9 & 38.9 \\
\hline $18: 3 n-3$ & 7.03 & 1.01 & 1.80 & 7.43 & 6.79 & 6.28 & 5.29 & 5.51 \\
\hline $\mathrm{SFA}^{1}$ & 15.8 & 74.8 & 23.1 & 16.5 & 31.5 & 45.4 & 23.4 & 24.0 \\
\hline$U_{F} A^{1}$ & 84.2 & 25.2 & 76.9 & 83.5 & 68.5 & 54.6 & 76.6 & 76.0 \\
\hline MUFA $^{1}$ & 25.4 & 14.1 & 41.1 & 23.6 & 20.5 & 16.9 & 27.9 & 30.9 \\
\hline PUFA $^{1}$ & 58.8 & 11.1 & 35.8 & 59.9 & 48.0 & 37.7 & 48.7 & 45.1 \\
\hline
\end{tabular}

${ }^{1}$ Included minor FAs

$S$ soybean oil, $H$ Hermetia illucens fat, $T$ Tenebrio molitor fat, $C$ control diet; $H 50$ and $\mathrm{H} 100$ diets with Hermetia illucens fat; $T 50$ and T100 diets with Tenebrio molitor fat, MUFA monounsaturated fatty acid, PUFA polyunsaturated fatty acid, SFA saturated fatty acid, UFA unsaturated fatty acid 


\section{Growth performance}

Table 3 reports the effects of the experimental diets on growth performance. After $41 \mathrm{~d}$ on trial, no differences were observed among the control and the experimental groups in terms of performance, morbidity and mortality. The final LW ranged from $2811 \mathrm{~g}$ (diet T50) to 2917 $\mathrm{g}$ (diet T100). The ADFI, ADG and FCR were $152 \mathrm{~g} / \mathrm{d}$, $44.5 \mathrm{~g} / \mathrm{d}$ and 3.44, respectively, on average for the five groups.

\section{Digestibility trial}

The ADC are reported in Table 4. The addition of $\mathrm{H}$ and $\mathrm{T}$ fats did not influence the digestibility of nutrients and energy. Only the digestibility of ADF tended to be lower in $\mathrm{T}$ diets compared to the control diet $(22.5 \%$ on average vs. $26.4 \% ; P=0.08$ ).

\section{Serum biochemistry parameters}

The different dietary $\mathrm{H}$ or $\mathrm{T}$ fat inclusion levels did not influence $(P>0.10)$ the serum biochemical parameters of the rabbits (Table 5). Only serum TP, cholesterol, LDH and phosphorus tended to differ among diets $(P \leq 0.10)$.

\section{Histomorphological investigations}

Villi height, crypt depth and their ratio were not affected by the experimental treatment (Table 6).

Histopathological alterations were present in all the organs of all rabbits regardless from the dietary treatments (Table 7). Multifocal to diffuse (especially centrilobular) vacuolar degeneration of the hepatocytes and focal to multifocal periportal and/or interstitial lymphoplasmacytic inflammation were identified in liver (Additional file 2). The spleen showed multifocal to diffuse white pulp hyperplasia or depletion. Finally, focal to multifocal interstitial lymphoplasmacytic inflammation was observed in kidney, with no degenerative changes being identified. Dietary inclusion of $\mathrm{H}$ or $\mathrm{T}$ fats did not

Table 3 Growth performance of rabbits fed the experimental diets ( $n=40$ rabbits/group)

\begin{tabular}{|c|c|c|c|c|c|c|c|}
\hline \multirow[t]{2}{*}{ Items } & \multicolumn{5}{|c|}{ Experimental diets } & \multirow[t]{2}{*}{ SEM } & \multirow{2}{*}{$\begin{array}{l}P- \\
\text { value }\end{array}$} \\
\hline & C & $\mathrm{H} 50$ & $\mathrm{H} 100$ & $\mathrm{~T} 50$ & $\mathrm{~T} 100$ & & \\
\hline Number of rabbits & 40 & 40 & 40 & 39 & 38 & & \\
\hline Initial live weight, g & 1039 & 1059 & 1068 & 1030 & 1057 & 9.7 & 0.74 \\
\hline Final live weight, g & 2907 & 2859 & 2880 & 2811 & 2917 & 21.3 & 0.54 \\
\hline$A D G, g / d$ & 45.6 & 43.9 & 44.2 & 43.5 & 45.1 & 0.43 & 0.53 \\
\hline$A D F I, g / d$ & 154 & 149 & 153 & 149 & 154 & 1.2 & 0.55 \\
\hline FCR & 3.40 & 3.44 & 3.52 & 3.45 & 3.41 & 0.02 & 0.38 \\
\hline Mortality, \% & 0 & 0 & 0 & 2.5 & 5.0 & - & 0.99 \\
\hline Morbidity, \% & 27.5 & 22.5 & 27.5 & 25.0 & 22.5 & - & 0.86 \\
\hline
\end{tabular}

C control diet, $\mathrm{H} 50$ and $\mathrm{H} 100$ diets with Hermetia illucens fat, T50 and T100 diets with Tenebrio molitor fat, SEM standard error of the means, ADG, daily weight gain, $A D F I$ daily feed intake, $F C R$ feed conversion ratio
Table 4 Rabbit feed intake and apparent digestibility coefficients during the digestibility trial ( $n=12 \mathrm{rabbits} /$ group)

\begin{tabular}{|c|c|c|c|c|c|c|c|}
\hline \multirow[t]{2}{*}{ Items } & \multicolumn{5}{|c|}{ Experimental diets } & \multirow[t]{2}{*}{ SEM } & \multirow{2}{*}{$\begin{array}{l}P \text { - } \\
\text { value }\end{array}$} \\
\hline & $\bar{C}$ & $\mathrm{H} 50$ & $\mathrm{H} 100$ & $\mathrm{~T} 50$ & $\overline{\mathrm{T} 100}$ & & \\
\hline Feed intake, g/d & 158 & 151 & 159 & 155 & 155 & 2.55 & 0.87 \\
\hline Dry matter, \% & 61.6 & 60.8 & 60.6 & 60.9 & 61.6 & 0.30 & 0.78 \\
\hline Organic matter, \% & 61.2 & 60.6 & 60.5 & 60.8 & 61.4 & 0.31 & 0.84 \\
\hline Crude protein, \% & 71.9 & 72.1 & 72.9 & 71.0 & 72.5 & 0.29 & 0.35 \\
\hline Ether extract, \% & 82.6 & 82.7 & 82.2 & 80.9 & 81.9 & 0.38 & 0.57 \\
\hline aNDF, \% & 33.5 & 32.0 & 32.2 & 32.0 & 30.2 & 0.50 & 0.44 \\
\hline Hemicelluloses, \% & 41.7 & 39.7 & 42.4 & 42.6 & 40.6 & 0.49 & 0.27 \\
\hline ADF, \% & 26.4 & 26.0 & 24.0 & 22.9 & 22.2 & 0.54 & 0.08 \\
\hline Energy, \% & 60.7 & 60.4 & 59.9 & 60.8 & 61.0 & 0.30 & 0.83 \\
\hline \multicolumn{8}{|l|}{ Nutritive value } \\
\hline $\mathrm{DP}, \mathrm{g} / \mathrm{kg}$ & 109.3 & 105.5 & 109.7 & 106.6 & 105.5 & - & - \\
\hline $\mathrm{DE}, \mathrm{MJ} / \mathrm{kg}$ & 10.0 & 10.1 & 9.9 & 10.2 & 10.2 & - & - \\
\hline DP/DE ratio, g/MJ & 10.9 & 10.5 & 11.1 & 10.5 & 10.4 & - & - \\
\hline
\end{tabular}

C control diet, $\mathrm{H} 50$ and $\mathrm{H} 100$ diets with Hermetia illucens fat, T50 and T100 diets with Tenebrio molitor fat, SEM standard error of the means, aNDF Neutral detergent fibre, $A D F$ Acid detergent fibre, $D P$ digestible protein, $D E$ digestible energy; $D P / D E$ ratio, digestible protein to digestible energy ratio

affect the severity of the histopathological alterations $(P>0.05)$.

\section{Discussion}

Only few papers investigated the effects of insect oils in poultry feeds $[16,17,20]$ and only two deals with the

Table 5 Effect of lipid sources on serum biochemical traits of rabbits fed experimental diets ( $n=15$ rabbits/group)

\begin{tabular}{|c|c|c|c|c|c|c|c|}
\hline \multirow[t]{2}{*}{ Items } & \multicolumn{5}{|c|}{ Experimental diets } & \multirow[t]{2}{*}{ SEM } & \multirow{2}{*}{$\begin{array}{l}P- \\
\text { value }\end{array}$} \\
\hline & C & $\mathrm{H} 50$ & $\mathrm{H} 100$ & T50 & T100 & & \\
\hline $\mathrm{TP}, \mathrm{g} / \mathrm{dL}$ & 5.4 & 5.1 & 5.1 & 5.1 & 5.1 & 0.04 & 0.08 \\
\hline AST, IU/L & 8.9 & 12.2 & 9.8 & 8.8 & 10.2 & 0.51 & 0.20 \\
\hline$A L T, I U / L$ & 42.5 & 43.1 & 45.2 & 47.2 & 40.3 & 1.13 & 0.38 \\
\hline$A L P, I U / L$ & 34.7 & 43.7 & 32.2 & 45.6 & 39.7 & 2.83 & 0.53 \\
\hline GGT, IU/L & 49.0 & 38.7 & 57.9 & 50.5 & 56.6 & 2.75 & 0.19 \\
\hline Uric acid, mg/dL & 1.5 & 1.4 & 1.5 & 1.5 & 1.5 & 0.03 & 0.99 \\
\hline Urea, mg/dL & 18.0 & 17.2 & 14.7 & 15.9 & 17.7 & 0.87 & 0.76 \\
\hline Creatinine, mg/dL & 0.6 & 0.7 & 0.8 & 0.8 & 0.8 & 0.04 & 0.53 \\
\hline Triglycerides, mg/dL & 123.0 & 122.8 & 120.4 & 126.1 & 103.1 & 6.79 & 0.84 \\
\hline Cholesterol, mg/dL & 47.4 & 52.6 & 45.7 & 38.3 & 51.4 & 1.82 & 0.10 \\
\hline $\mathrm{LDH}, \mathrm{IU} / \mathrm{L}$ & 143.5 & 146.9 & 120.7 & 199.9 & 117.4 & 10.4 & 0.09 \\
\hline Iron, $\mu \mathrm{g} / \mathrm{dL}$ & 293.0 & 60.8 & 242.1 & 289.3 & 312.2 & 13.1 & 0.47 \\
\hline Calcium, mg/dL & 9.5 & 11.2 & 10.0 & 9.9 & 10.2 & 0.39 & 0.73 \\
\hline Phosphorous, mg/dL & 6.8 & 7.6 & 9.3 & 7.7 & 6.6 & 0.34 & 0.08 \\
\hline
\end{tabular}

$\mathrm{C}$ control diet, $\mathrm{H} 50$ and $\mathrm{H} 100$ diets with Hermetia illucens fat, T50 and T100 diets with Tenebrio molitor fat, SEM standard error of the means, TP total proteins, AST aspartate-aminotransferase, ALT alanine-aminotransferase, ALP alkaline phosphatase, GGT Gamma-glutamyl transferase, $L D H$ lactic acid dehydrogenase 
Table 6 Effects of lipid sources on the gut morphometric indices of rabbits ( $n=15 \mathrm{rabbits} / \mathrm{group}$ )

\begin{tabular}{|c|c|c|c|c|c|c|c|}
\hline \multirow[t]{2}{*}{ Items } & \multicolumn{5}{|c|}{ Experimental diets } & \multirow[t]{2}{*}{ SEM } & \multirow{2}{*}{$\begin{array}{l}P- \\
\text { value }\end{array}$} \\
\hline & $\mathrm{C}$ & $\mathrm{H} 50$ & $\mathrm{H} 100$ & T50 & $\mathrm{T100}$ & & \\
\hline \multicolumn{8}{|l|}{ Duodenum } \\
\hline Vh, mm & 1.69 & 1.43 & 1.58 & 1.67 & 1.59 & 0.08 & 0.56 \\
\hline $\mathrm{Cd}, \mathrm{mm}$ & 0.09 & 0.09 & 0.08 & 0.09 & 0.09 & 0.004 & 0.92 \\
\hline $\mathrm{Vh} / \mathrm{Cd}$ & 18.55 & 16.95 & 18.60 & 20.73 & 18.14 & 0.64 & 0.49 \\
\hline \multicolumn{8}{|l|}{ Jejunum } \\
\hline Vh, mm & 1.53 & 1.50 & 1.69 & 1.68 & 1.63 & 0.07 & 0.51 \\
\hline $\mathrm{Cd}, \mathrm{mm}$ & 0.09 & 0.08 & 0.08 & 0.08 & 0.08 & 0.003 & 0.99 \\
\hline $\mathrm{Vh} / \mathrm{Cd}$ & 18.76 & 18.03 & 22.29 & 20.24 & 20.15 & 0.77 & 0.51 \\
\hline \multicolumn{8}{|l|}{ Ileum } \\
\hline Vh, mm & 1.02 & 1.35 & 1.24 & 1.40 & 1.25 & 0.08 & 0.55 \\
\hline $\mathrm{Cd}, \mathrm{mm}$ & 0.08 & 0.09 & 0.09 & 0.08 & 0.09 & 0.004 & 0.80 \\
\hline $\mathrm{Vh} / \mathrm{Cd}$ & 13.47 & 15.77 & 14.85 & 17.27 & 15.17 & 0.46 & 0.12 \\
\hline
\end{tabular}

$\mathrm{C}$ control diet, $\mathrm{H} 50$ and $\mathrm{H} 100$ diets with Hermetia illucens fat, T50 and T100 diets with Tenebrio molitor fat, SEM standard error of the means, Vh villi height, $C d$ crypt depth, $\mathrm{Vh} / \mathrm{Cd}$ villus height to crypt depth ratio

inclusion of insect fat in growing rabbit diets [23, 24]. The results obtained in this study are consistent with the hypothesis enunciated in the background and showed how the dietary insect oil inclusion did not negatively affected performances, digestibility, gut mucosa and rabbit health.

\section{Growth performance and nutrient digestibility}

At the end of the growing period, no statistical differences among groups were reported for the growth performance traits. During the trial, the rabbits were not treated with antibiotics and the mortality was low and not influenced by dietary treatment. The similar feed intake indicated that $0.75 \%$ and $1.50 \%$ inclusion levels of both insect fats were acceptable to growing rabbits. A

Table 7 Effects of lipid sources on the histopathological scores of rabbits ( $n=15$ rabbits/group)

\begin{tabular}{|c|c|c|c|c|c|c|c|}
\hline \multirow[t]{2}{*}{ Items } & \multicolumn{5}{|c|}{ Experimental diets } & \multirow[t]{2}{*}{ SEM } & \multirow{2}{*}{$\begin{array}{l}P- \\
\text { value }\end{array}$} \\
\hline & $\mathrm{C}$ & $\mathrm{H} 50$ & $\mathrm{H} 100$ & T50 & $\mathrm{T} 100$ & & \\
\hline \multicolumn{8}{|l|}{ Liver } \\
\hline Inflammation score & 1.21 & 1.21 & 0.88 & 0.67 & 0.79 & 0.11 & 0.42 \\
\hline Degeneration score & 1.46 & 1.79 & 1.33 & 1.17 & 1.64 & 0.12 & 0.35 \\
\hline \multicolumn{8}{|l|}{ Kidney } \\
\hline Inflammation score & 0.64 & 0.79 & 0.67 & 0.50 & 0.57 & 0.11 & 0.91 \\
\hline Degeneration score & \multicolumn{7}{|c|}{ Absence of degenerative changes } \\
\hline \multicolumn{8}{|l|}{ Spleen } \\
\hline White pulp hyperplasia & 0.14 & 0.14 & 0.00 & 0.00 & 0.14 & 0.05 & 0.79 \\
\hline White pulp depletion & 0.29 & 0.14 & 0.00 & 0.17 & 0.29 & 0.07 & 0.71 \\
\hline
\end{tabular}

$\mathrm{C}$ control diet, $\mathrm{H} 50$ and $\mathrm{H} 100$ diets with Hermetia illucens fat, T50 and T100 diets with Tenebrio molitor fat, SEM standard error of the means preference test where poultry were free to choose between diets containing $\mathrm{H}$ or $\mathrm{S}$ fats did not reveal any difference, confirming a good acceptability of both insect lipid sources [20]. Our data are fully consistent with those reported by Martins et al. [25] who observed unaffected growth performances in growing rabbits fed $\mathrm{H}$ fat with two inclusion level of supplementation in comparison to two inclusion levels of extruded linseed. Consistently with our results, in poultry, Schiavone et al. [17, 20] reported that partial or full replacement of $S$ with $H$ fat had no effect on birds growth performance or health. Similarly, the use of 5\% of $\mathrm{T}$ or Zophobas morio fats in total substitution of $\mathrm{S}$ in a 28-day trial did not affect the growth and feed efficiency of broiler chickens [16].

As far as fish are concerned, Li et al. [15] studied the effect of increasing the replacement rate of $\mathrm{S}$ with $\mathrm{H}$ fat on juvenile Jian carp (Cyprinus carpio var. Jian) and reported no differences on growth performance and nutrient utilization. Recently, Dumas et al. [36] evaluated up to $10 \%$ of $\mathrm{H}$ fat dietary inclusion in partial or total substitution of fish oil in diets for rainbow trout and reported no significant effect on final body weight, weight gain, FCR and mortality.

Other researches using different (animal and vegetable) oils and fats in rabbit diets did not find significant differences in growth performance, indicating that rabbit can digest and metabolize different lipid sources, at least until 3\% of inclusion level [3]. For instance, both Rodríguez et al. [37] and Kowalska and Bielanski [38] found similar growth performance and feed conversion efficiency when feeding rabbits with lard fat, fish or soybean oils. Also, Trebušak et al. [39] showed similar growth performance in rabbits fed diets containing palm fat (rich in SFA) or linseed oil (rich in PUFA). Peiretti et al. [40] did not find differences in growth performance of rabbits fed diets supplemented with maize or palm oil. The lack of an effect of the lipid source on growth performance was also reported by Chen and $\mathrm{Li}$ [41] when lard was added to rabbit diets instead of $\mathrm{S}$, as well as by Casado et al. [42] feeding fattening rabbits with diets containing $3 \%$ of animal fat (lard), vegetable sources (sunflower or linseed oils) or a 1:1 mixture of sunflower oil and lard or linseed oil and lard. Conversely, Djakalia et al. [43] reported higher performance in growing rabbits fed $\mathrm{S}$ diet compared to those fed palm oil diet and ascribed this effect to the higher PUFA and lower SFA levels of the former. Differences among studies could depend more on the different fat levels tested [2] than the lipid source [3]. Indeed, in our trial, dietary fat level was maintained around standard values for growing rabbits [25]. Likely, at higher inclusion levels, differences in FA profile among the different added fat could have caused large differences in fat digestive utilization and thus in growth $[2,3]$. 
To go in deep on the evaluation of dietary treatments on nutrient digestibility, in the present trial DM and energy digestibility coefficients were high and similar in all treatments indicating that both insect lipid sources are suitable for rabbit feeding. As the digestibility of EE is concerned, the mean value was consistent with literature data. Differences may depend on the type of fat source, their unsaturation degree as well as the level of structural lipids linked to cell walls $[3,44,45]$. In fact, the digestibility of more saturated fats, like tallow and lard, may be lower than that of unsaturated fat, like sunflower and soybean oils [46]. However, in the current study, the higher levels of SFA of $\mathrm{H}$ diets, did not determine $\mathrm{EE}$ digestibility lower than $\mathrm{C}$ or $\mathrm{T}$ diets. Similarly, in diets for rainbow trout, Dumas et al. [36] did not find significant differences for EE digestibility when $20 \% \mathrm{H}$ fat was added to diets. Also, Chen and Li [41] did not observe significant difference in the EE digestibility depending on the FA profile of the lipid source (lard vs soybean oil) in diets for growing rabbits.

In the contrary, Martins et al. [24] reported that $\mathrm{H}$ fat with two inclusion level in growing rabbit's diet decreased the ADC of DM, OM, EE and GE when compared to linseed fat source. The authors found that increasing the level of $\mathrm{H}$ fat in the diets led to a significant increase in the ADC of EE and a significant decrease in the ADC of the cellulose.

\section{Serum biochemistry traits}

In the current trial, the values of the different traits lay within the normal range for rabbits [47-49]. This suggests that the rabbits were within physiological conditions. In our trial, only the type of fat included were different and diets had the same nutrient levels. This could justify the lack of significant differences in TP values between groups. Indeed, Iyayi and Tewe [50]. reported that serum TP synthesis is generally related to the content of available protein in the diet. Including insect lipids in rabbit diets did not influence AST, ALT and ALP enzyme activities, which are considered to be important indicators of liver functions [51].

Indeed, also in broiler chickens, Schiavone et al. [17, 20] showed that dietary partial or total replacement of $S$ with $\mathrm{H}$ fat did not affect serum biochemistry parameters. The same finding was reported with Li et al. [15] in juvenile Jian carp fed diets with different substitution levels of $\mathrm{S}$ with $\mathrm{H}$ fat.

\section{Histomorphological investigations}

Since both gut morphology and growth performance were unaffected in $\mathrm{H}$ and $\mathrm{T}$ groups of the current research, insect lipids utilization did not negatively influence gut development and functionality. Consistently with the results of the present study, Schiavone et al.
[17] observed unaffected intestinal morphometric indices in broiler chickens fed with $\mathrm{H}$ fat replacing $50 \%$ or $100 \%$ of S.

Dietary $\mathrm{H}$ or $\mathrm{T}$ fat inclusion did not affect either the development or the severity of the histopathological alterations in the rabbits of the current research. Degenerative and inflammatory changes of liver and kidney are usually observed in toxic diseases [52] or toxicity-induced oxidative stress conditions [53]. Hepatic and renal oxidative stress development has also been reported in rabbits fed with hypercholesterolemic diets [54], thus underlying the impact of dietary lipid modifications on liver and kidney functionality. However, no hypercholesterolemia was observed in $\mathrm{H}$ and $\mathrm{T}$ rabbits of the present study. Furthermore, the majority of the histopathological alterations varied from absent to moderate in all the dietary treatments and they were also identified in the animals fed with $\mathrm{C}$ diet, thus allowing to reliably exclude a potential influence of insect lipids utilization in their development.

\section{Conclusions}

The obtained results showed that $\mathrm{H}$ and $\mathrm{T}$ fats can be used as partial or total substitute of soybean oil until $1.5 \%$ of the diet in rabbit feeding without impacting growth performance, nutrient digestibility, serum biochemical traits and gut development. These findings suggest that $\mathrm{H}$ and $\mathrm{T}$ fats is a suitable ingredient for rabbit diets. However, further studies should be performed to establish the most effective source and to determine the optimal inclusion level of insect lipids for rabbit feeding.

\section{Additional files}

Additional file 1: Morphometric evaluation of the jejunum segment of the rabbits. Morphometric measurements of the villus height (Vh) and the crypt depth (Cd). H100 group, 2.5x haematoxylin-eosin stain. (TIF 7150 kb)

Additional file 2 Histopathological findings of the rabbits. (A) HI50 group. A normal liver is observed. 10x haematoxylin-eosin stain. (B) H100 group. Liver, periportal zone. Moderate and multifocal vacuolar degeneration of the hepatocytes (arrowheads), as well as mild and multifocal lymphoplasmacytic inflammation (arrows), are identified. 10x haematoxylin-eosin stain. (TIF $5050 \mathrm{~kb})$

\section{Abbreviations}

ADC: Apparent digestibility coefficient; ADF: Acid detergent fibre; ADFI: Daily feed intake; ADG: Daily weight gain; ADL: Acid detergent lignin; ALP: Alkaline phosphatase; ALT: Alanine amino-transferase; aNDF: Neutral detergent fibre; AST: Aspartate amino-transferase; C: Control diet; Cd: Crypt depth; CP: Crude protein; DE: Digestible energy; DM: Dry matter; DP: Digestible protein; EE: Ether extract; FA: Fatty acid; FAME: Fatty acids methyl esters; FCR: Feed conversion ratio; GE: Gross energy; GGT: Gamma-glutamyl transferase; $\mathrm{H}$ : Hermetia illucens; HE: Haematoxylin-eosin; $\mathrm{HR}_{\mathrm{i}}$ : Health risk index; LDH: Lactic acid dehydrogenase; LW: Live weight; MUFA: Monounsaturated fatty acid; PUFA: Polyunsaturated fatty acid; S: Soybean oil; SEM: Standard error of the means; SFA: Saturated fatty acid; T: Tenebrio molitor; TP: Total proteins; UFA: Unsaturated fatty acid; Vh / Cd: Villus height to crypt depth ratio; Vh: Villus height 


\section{Acknowledgments}

The authors gratefully acknowledge Dr. Andrea Dama, Dr. Enrico Bressan, Mr. Dario Sola and Mr. Mario Colombano for technical support, and Ynsect and Hermetia Deutschland GmbH \& Co. KG for the provision of the insect fats.

\section{Funding}

Financial support for this work was provided by the University of Turin (ex 60\%) grants (Es. fin. 2015-2016-2017).

\section{Availability of data and materials}

The datasets analysed in the current study are available from the corresponding author on reasonable request.

\section{Authors' contributions}

$L G, S D, A T, G X, A S$ and FG conceived and designed the experiment. AT and GX formulated the experimental diets and carried out their analyses. $L G, S D$, $M M, A S$ and FG prepare the diets and performed the trial. $L G, S D, I B, M B$, $\mathrm{MM}$ and $\mathrm{AS}$ collected the experiments data. MTC and IB performed the morphometric investigations. DD established the blood parameters. SD and IB performed the statistical analysis. All authors analysed and interpret the data. LG, SD, AT, IB and FG wrote the first draft of the manuscript. All authors critically reviewed the manuscript for intellectual content and gave final approval for the version to be published.

\section{Ethics approval and consent to participate}

The trial was designed according to the guidelines of the current European Directive (2010/63/EU) on the care and protection of animals used for scientific purposes. The experimental protocol was approved by the Ethical Committee of the University of Turin (Italy) (Ref. 386,638, 4/12/2017).

\section{Consent for publication}

Not applicable.

\section{Competing interests}

The authors declare that they have no competing interests.

\section{Author details}

'Department of Agricultural, Forest and Food Science, University of Turin Largo Paolo Braccini 2, 10095 Grugliasco, Turin, Italy. ${ }^{2}$ Department of Veterinary Science, University of Turin, Largo Paolo Braccini 2, 10095 Grugliasco, Turin, Italy. ${ }^{3}$ Department of Comparative Biomedicine and Food Science, University of Padova, Viale dell'Università 16, 35020 Legnaro, Padova, Italy. ${ }^{4}$ Department of Agronomy Food Natural Resources Animal and Environment, University of Padova, Viale dell'Università 16, 35020 Legnaro, Padova, Italy. ${ }^{5}$ Veterinary Medical Research Institute for Piemonte, Liguria and Valle d'Aosta, Via Bologna 148, 10154 Turin, Italy. ${ }^{6}$ Institute of Science of Food Production, National Research Council, Largo Paolo Braccini 2, 10095 Grugliasco, Turin, Italy. ${ }^{7}$ Institute of Interdisciplinary Research on Sustainability, University of Turin, Via Accademia Albertina 13, 10100 Turin, Italy.

\section{Received: 18 September 2018 Accepted: 18 December 2018}

\section{Published online: 17 January 2019}

\section{References}

1. Maertens L. Fats in rabbit nutrition: a review. World Rabbit Sci. 1998;6:341-8.

2. Fernández-Carmona J, Pascual JJ, Cervera C. The use of fat in rabbit diets. Valencia: 7th World Rabbit Congress. July 4-7; 2000. p. 29-59.

3. Xiccato G. Fat digestion. In: De Blas C, Wiseman J, editors. The Nutrition of the Rabbit. Nutrition of the rabbit. 2nd ed. Oxon (UK): CAB International; 2010. p. 56-65.

4. Publishing Group in FAO's Office for Corporate Communication. FAO ( Food and Agricultural Organization of the United Nations). Rome: World Livestock 2011 - Livestock in food security; 2011.

5. Henry M, Gasco L, Piccolo G, Fountoulaki E. Review on the use of insects in the diet of farmed fish: past and future. Anim Feed Sci Technol. 2015;203:1-22.

6. Sánchez-Muros MJ, Barroso FG, Manzano-Agugliaro F. Insect meal as renewable source of food for animal feeding: a review. J Clean Prod. 2015;65:16-27.

7. Renna M, Schiavone A, Gai F, Dabbou S, Lussiana C, Malfatto V, et al. Evaluation of the suitability of a partially defatted black soldier fly (Hermetia illucens L.) larvae meal as ingredient for rainbow trout (Oncorhynchus mykiss Walbaum) diets. J Anim Sci Biotechnol. 2017;8:957-69.
8. Biasato I, Gasco L, De Marco M, Renna M, Rotolo L, Dabbou S, et al. Yellow mealworm larvae (Tenebrio molitor) inclusion in diets for male broiler chickens: effects on growth performance, gut morphology, and histological findings. Poult Sci. 2018;97:540-8.

9. Dabbou S, Gai F, Biasato I, Capucchio MT, Biasibetti E, Dezzutto D, et al. Black soldier fly defatted meal as a dietary protein source for broiler chickens: Effects on growth performance, blood traits, gut morphology and histological features. J Animal Sci Biotechnol. 2018;9:49.

10. Piccolo G, Marono S, Bovera F, Gasco L, Parisi G, Loponte R, et al. Effect of Tenebrio molitor larvae meal on growth performance, in vivo nutrients digestibility, somatic and marketable indexes of gilthead sea bream (Sparus aurata). Anim Feed Sci Technol. 2017;226:12-20.

11. Spranghers T, Ottoboni M, Klootwijk C, Ovyn A, Deboosere S, De Meulenaer $\mathrm{B}$, et al. Nutritional composition of black soldier fly (Hermetia illucens) prepupae reared on different organic waste substrates. J Sci Food Agric. 2017;97:2594-600.

12. Meneguz M, Schiavone A, Gai F, Dama A, Lussiana C, Renna M, et al. Effect of rearing substrate on growth performance, waste reduction efficiency and chemical composition of black soldier fly (Hermetia illucens) larvae. J Sci Food Agric. 2018. https://doi.org/10.1002/jsfa.9127.

13. Surendra KC, Olivier R, Tomberlin JK, Jha R, Khanal SK. Bioconversion of organic wastes into biodiesel and animal feed via insect farming. Renew Energy. 2016;98:197-202

14. Schiavone A, De Marco M, Martinez S, Dabbou S, Renna M, Madrid J, et al. Nutritional value of a partially defatted and a highly defatted black soldier fly larvae (Hermetia illucens L.) meal for broiler chickens: apparent nutrient digestibility, apparent metabolizable energy and apparent ileal amino acid digestibility. J Anim Sci Biotechnol. 2017a;8: 897-905.

15. Li L, Ji H, Zhang B, Tian J, Zhou J, Yu H. Influence of black soldier fly (Hermetia illucens) larvae oil on growth performance, body composition, tissue fatty acid composition and lipid deposition in juvenile Jian carp (Cyprinus carpio var. Jian). Aquaculture. 2016;465:43-52.

16. Kierończyk B, Rawski M, Józefiak A, Mazurkiewicz J, Świątkiewicz S, Siweke $M$, et al. Effects of replacing soybean oil with selected insect fats on broilers. Anim Feed Sci Technol. 2018. https://doi.org/10.1002/jsfa.9127, https://doi. org/10.1016/j.anifeedsci.2018.04.002.

17. Schiavone A, Dabbou S, De Marco M, Cullere M, Biasato I, Biasibetti E, et al. Black soldier fly (Hermetia illucens L.) larva fat inclusion in finisher broiler chicken diet as an alternative fat source. Anim. 2018. https://doi.org/10. 1017/S1751731117003743.

18. Diener S, Studt Solano NM, Roa Gutierrez F, Zurbrugg C, Tockner K. Biological treatment of municipal organic waste using black soldier fly larvae. Waste Biomass Valor. 2011;2:357-63.

19. Gasco L, Gai F, Maricchiolo G, Genovese L, Ragonese S, Bottari T, et al. Fish meal alternative protein sources for aquaculture feeds. In: Chemistry of foods: Feeds for the aquaculture sector - Current situation and alternative sources. SpringerBriefs in Molecular Science. Lightning Source UK Ltd; 2018. p. 1-28.

20. Schiavone A, Cullere M, De Marco M, Meneguz M, Biasato I, Bergagna S, et al. Partial or total replacement of soybean oil by black soldier lanvae (Hermetia illucens L.) fat in broiler diets: effect on growth performances, feed-choice, blood traits, carcass characteristics and meat quality. Ital J Anim Sci. 2017b;16:93-100.

21. Carregal RD, Takahashi R. Use of silkworm (Bombyx mori L.) chrysalis meal as a replacement for soyabean meal in the feeding of growing rabbits. Rev Soc Bras Zoot. 1987;16:158-62.

22. Liu ML, Tang LM, Yan JP, Liu YG. Effects of concentrated rapeseed protein on growing rabbits. J Sichuan Agric Univ. 1987;2:20-2.

23. Dalle Zotte A, Cullere M, Martins C, Alves SP, Freire JPB, Falcão-e-Cunha L, et al. Incorporation of black soldier fly (Hermetia illucens L.) larvae fat or extruded linseed in diets of growing rabbits and their effects on meat quality traits including detailed fatty acid composition. Meat Sci. 2018;146:50-8.

24. Martins C, Cullere M, Dalle Zotte A, Cardosi C, Alves AP, et al. Incorporation of two levels of black soldier fly (Hermetia illucens L.) larvae fat or extruded linseed in diets of growing rabbits: effects on growth performance and diet digestibility. Czech J Anim Sci. 2018;63:356-62.

25. de Blas C, Mateos GG. Feed formulation. In: de Blas C, Wiseman J, editors. Nutrition of the rabbit. 2nd ed. Oxon (UK): CAB International; 2010. p. 89-01.

26. Gidenne T, Combes S, Feugier A, Jehl N, Arveux P, Boisot P, et al. Feed restriction strategy in the growing rabbit. 2 . Impact on digestive health, growth and carcass characteristics. Anim. 2009;3:509-15. 
27. Perez JM, Lebas F, Gidenne T, Maertens L, Xiccato G, Parigi-Bini R, et al. European reference method for in vivo determination of diet digestibility in rabbits. World Rabbit Sci. 1995;3:41-3.

28. AOAC. International official methods of analysis of AOAC Inernational. 17th ed. Association of Official Analytical Chemists: Arlington, VA; 2000.

29. Gidenne T, Perez JM, Xiccato G, Trocino A, Carabaño R, Villamide MJ, et al. Technical note: attempts to harmonize chemical analyses of feeds and faeces, for rabbit feed evaluation. World Rabbit Sci. 2001;9:57-64.

30. EC. Commission Directive 98/64/EC of 3 September 1998 establishing Community methods of analysis for the determination of amino acids, crude oils and fats, and olaquindox in feeding stuffs and amending. Directive 71/393/ EEC. Off. J Eur Union 1998; L257/14.

31. Mertens DR. Gravimetric determination of amylase-treated neutral detergent fiber in feeds with refluxing in beakers or crucibles: collaborative study. J AOAC Int. 2002:85:1217-40.

32. Van Soest PJ, Robertson JB, Lewis BA. Methods for dietary fiber, neutral detergent fiber, and non-starch polysaccharides in relation to animal nutrition. J Dairy Sci. 1991;74:3583-97.

33. Trocino A, Birolo M, Dabbou S, Gratta F, Rigo N, Xiccato G. Effect of age and gender on carcass traits and meat quality of farmed brown hares. Animal. 2018;12:864-71.

34. Iser M, Martínez $Y, N_{i} H$, Jiang $H$, Valdivié Navarro $M$, Wu X, et al. The effects of agave fourcroydes powder as a dietary supplement on growth performance, gut morphology, concentration of lgG, and hematology parameters in broiler rabbits. Biomed Res Int. 2016;2016:3414319.

35. Tůmová E, Volek Z, Chodová D, Härtlová H, Makovický P, Svobodová J, et al. The effect of 1-week feed restriction on performance, digestibility of nutrients and digestive system development in the growing rabbit. Animal. 2016;10:1-9.

36. Dumas A, Raggi T, Barkhouse J, Lewis E, Weltzien E. The oil fraction and partially defatted meal of black soldier fly larvae (Hermetia illucens) affect differently growth performance, feed efficiency, nutrient deposition, blood glucose and lipid digestibility of rainbow trout (Oncorhynchus mykiss). Aquaculture. 2018;492:24-34

37. Rodríguez M, Carro MD, Valiente V, Formoso-Rafferty N, Rebollar PG. Effects of dietary fish oil supplementation on performance, meat quality, and cecal fermentation of growing rabbits. J Anim Sci. 2017;95:3620-30 (Abstr).

38. Kowalska D, Bielanski P. Meat quality of rabbit fed a diet supplemented with fish oil and antioxidant. Anim Sci Pap Rep. 2009:27:139-48.

39. Trebušak T, Levart A, Salobir J, Pirman T. A higher proportion of PUFA in diet increases the PUFA content in rabbit meat, but reduces the oxidative stability of meat. Poljoprivreda. 2015;21:73-7.

40. Peiretti $P G$, Masoero G. Effects of replacing palm oil with maize oil and Curcuma longa supplementation on the performance, carcass characteristics, meat quality and fatty acid profile of the perirenal fat and muscle of growing rabbits. Animal. 2011;5:795-801.

41. Chen P, Li FC. Effect of dietary fat addition on growth performance, nutrient digestion and caecum fermentation in 2-3 months old meat rabbits. Verona: 9th World Rabbit Congress; 2008. June 10-13 2008. p. 589-93.

42. Casado C, Moya VJ, Pascual JJ, Blas E, Cervera C. Effect of oxidation state of dietary sunflower oil and dietary zinc and a-tocopheryl acetate supplementation on performance of fattening rabbits. World Rabbit Sci. 2011;19:191-202.

43. Djakalia B, Guichard BL, Fernande AE. Effect of palm oil and soya bean oil on growth performance and health of rabbit before and after weaning. J Appl Anim Res. 2012;40:56-62.

44. Maertens L, Huyghebaert G, De Groot G. Digestibility and digestible energy content of various fat for growing rabbits. Cuni-Sciences. 1986;3:7-11.

45. Pascual JJ, Motta W, Cervera C, Quevedo F, Blas E, Fernández-Carmona J. Effect of dietary energy source on the performance and perirenal fat thickness evolution of primiparous rabbit does. Anim Sci. 2002:75:267-79.

46. Santomá G, de Blas JC, Carabaño RM, Fraga MJ. The effects of different fats and their inclusion level in diets for growing rabbits. Anim Sci. 1987:45:291-300.

47. McLaughlin RM, Fish RE. Clinical biochemistry and hematology. In: Manning PJ, Ringler DH, Newcomer CE, editors. The biology of the laboratory rabbit. 2nd ed. London 24-28 Oval Rd NW1 7DX: Academic Press Limited; 1994. p. 111-30.

48. Melillo A. Rabbit clinical pathology. J Exot Pet Med. 2007;16:135-45.

49. Özkan C, Kaya A, Akgül Y. Normal values of haematological and some biochemical parameters in serum and urine of New Zealand white rabbits. World Rabbit Sci. 2012:20:253-9.
50. Iyayi $\mathrm{E}$, Tewe $\mathrm{OO}$. Serum total protein urea and creatine levels as indices of quality of cassava diets for pigs. Trop Vet. 1998;16:59-67.

51. Celik I, Suzek H. The hematological effects of methyl parathion in rats. J Hazard Mater. 2008;153:1117-21.

52. Amer SA, Kishawy ATY, ELseddawy NM, Abd El-Hack ME. Impacts of bentonite supplementation on growth, carcass traits, nutrient digestibility, and histopathology of certain organs of rabbits fed diet naturally contaminated with aflatoxin. Environ Sci Pollut Res Int. 2018;25:1340-9.

53. Tsitsimpikou C, Tzatzarakis M, Fragkiadaki P, Kovatsi L, Stivaktakis $P$, Kalogeraki A, et al. Histopathological lesions, oxidative stress and genotoxic effects in liver and kidneys following long term exposure of rabbits to diazinon and propoxur. Toxicology. 2013;307:109-14.

54. Prasad K, McNair ED, Qureshi AM, Casper-Bell G. Vitamin E slows the progression of hypercholesterolemia-induced oxidative stress in heart, liver and kidney. Mol Cell Biochem. 2012;368:181-7.
Ready to submit your research? Choose BMC and benefit from:

- fast, convenient online submission

- thorough peer review by experienced researchers in your field

- rapid publication on acceptance

- support for research data, including large and complex data types

- gold Open Access which fosters wider collaboration and increased citations

- maximum visibility for your research: over $100 \mathrm{M}$ website views per year

At $\mathrm{BMC}$, research is always in progress.

Learn more biomedcentral.com/submissions 